\title{
MENINGKATKAN HASIL BELAJAR SISWA MENGGUNAKAN MODEL PEMBELAJARAN KOOPERATIF TIPE NUMBERED HEAD TOGETHER PADA MATA PELAJARANMATEMATIKA DI KELAS V
}

\author{
JUNIKO ESRA TARIGAN DAN ANANDA AYU MUTIARA \\ Prodi PGSD FKIP Universitas Quality
}

\begin{abstract}
ABSTRAK
Tujuan dilakukan penelitian adalah untuk memperbaiki pembelajaran dan meningkatkan hasil belajar siswa dengan menggunakan model pembelajaran kooperatif tipe Numbered Head Together pada mata pelajaran matematika materi pembagian pecahan biasa dengan pecahan campuran.Masalah dalam penelitian adalah rendahnya hasil belajar siswa pada mata pelajaran matematika.Penelitian yang dilakukan berbentuk penelitian tindakan kelas. Subjek penelitian adalah siswa kelas V SD Negeri 066668 Medan Johor Tahun Ajaran 2016/2017 dengan jumlah siswa 40 terdiri dari 19 siswa laki-laki dan 21 siswa perempuan. Penelitian terdiri dari siklus I dan siklus II.Alat pengumpul data adalah soal tes dalam bentuk essay sebanyak 4 soal.

Dari data hasil penelitian diperoleh hasil observasi pelaksanaan pembelajaran aktivitas guru meningkat $21,38 \%$ dari skor $59,69 \%$ menjadi $72,45 \%$, aktivitas siswa meningkat 29,41\% dari skor 68 menjadi 88, ketuntasan individu mencapai nilai KKM yaitu 70, secara klasikal meningkat 29,63\% dari persentase $67,5 \%$ menjadi $87,5 \%$ dan nilai rata-rata meningkat $7,22 \%$ dari 69,43 menjadi 74,45 .

Dari hasil penelitian dapat disimpulkan bahwa pelaksanaan pembelajaran berkriteria baik dan hasil belajar siswa meningkat setelah menggunakan model pembelajaran kooperatif tipe Numbered Head Together pada mata pelajaran matematika materi pembagian pecahan biasa dengan pecahan campuran di kelas V SD Negeri 066668 Medan Johor Tahun Ajaran 2016/2017.
\end{abstract}

\section{Kata Kunci : Hasil Belajar, Model Pembelajaran Kooperatif Tipe Numbered Head Together}

\begin{abstract}
ANANDA AYU MUTIARA, NPM 1305030167 "Improving of Student Learning Outcomes by Cooperative Learning Model Numbered Head Together Type of Math Story Studies in V Grade Class National Elementary School 066668 of Medan Johor 2016/2017 in years".

This research was held aims to fix learning and increase students learning output by cooperative learning model Numbered Head Together in type at math studies of common fraction distribution compare in mix fractional material. The main problems in this research so down exam outcomes of students
\end{abstract}


in math studies indeed. The type of research is in classroom based action research. The subjects of this are who they has member of class $\mathrm{V}$ grade in national elementary school students 066668 Medan Johor being at 2016/2017 years entry within 40 students in a class and got to stand by 19 male students and 21 female students in are. The step of this research was due to two sessional that are part 1 and part 2 in a while. Tools of data collected had exam tests in essay form in a much 4 essay.

By data of result outcomes within observation found by implementation of learning, teacher activity conducted growing up in 21,38\% came from 59,69\% score to $72,45 \%$. Students activity told to growing $29,41 \%$ came from 68 to 88 in value, to individual completed when they should got 70 point in KKM, in classical look up in $29,63 \%$ from percentage of $67,5 \%$ to $87,5 \%$ and point of mean got up from 69,43 to 74,45 .

The conclusion by this research told to by the implemented of studies conducted the great criteria and outcomes studies had advance applied after by cooperative learning model in Numbered Head Together typed at the math stories studies within common fraction distribution compare in mix fractional material in V grade of class national elementary school 066668 Medan Johor 2016/2017 in years.

\section{Keyword : Learning Outcomes, Cooperative Learning Model Numbered Head Together Type}

\section{PENDAHULUAN}

Pendidikan merupakan suatu proses pengembangan diri individu dari kepribadian seseorang yang dilakukan secara sadar dan penuh tangggung jawab untuk dapat meningkatkan pengetahuan, keterampilan, dan sikap serta nilainilai sehingga mampu menyesuaikan diri dengan lingkungan.

Proses belajar mengajar merupakan suatu proses yang rumit karena tidak sekedar menyerap informasi dari guru, tetapi melibatkan berbagai kegiatan maupun tindakan yang dilakukan, terutama bila diinginkan hasil belajar yang lebih baik atau maksimal. Belajar mengajar pada hakikatnya merupakan suatu upaya dalam mengembangkan dan membangkitkan keaktifan belajar yang dilakukan oleh siswa dan guru. Djamarah dan Aswan (2014: 44) menyatakan "Kegiatan belajar mengajar adalah inti kegiatan dalam pendidikan". Proses belajar yang dialami setiap siswa terjadi secara abstrak, karena terjadi secara mental dan tidak dapat diamati, dapat diketahui jika ada perubahan perilaku yang berbeda dari seseorang 
Berdasarkan hasil observasi awal yang peneliti lakukan di SD Negeri 066668 Medan Johor bahwa dari 40 siswa, 18 orang $(45,00 \%)$ dari jumlah siswa sebanyak 40 orang mendapat nilai di bawah KKM, sedangkan yang mendapatkan nilai di atas atau sama dengan KKM sebanyak 22 orang $(55,00 \%)$ dan rata-rata keseluruhan adalah 62,00. Dengan hasil tabel tersebut menjelaskan hasil belajar siswa belum mencapai standar ketuntasan klasikal yaitu $85 \%$.

Kurang maksimalnya hasil belajar pada materi pembagian pecahan biasa dengan pecahan campuran disebabkan oleh beberapa faktor penyebab diantaranya dari faktor guru dan siswa. Berdasarkan informasi dari Kepala Sekolah dari faktor guru antara lain; (1) Proses pembelajaran masih didominasi oleh guru, (2) Dalam proses belajar di kelas, guru memakai model pembelajaran yang kurang bervariasi dan cenderung hanya menyampaikan materi serta pemberian tugas, (3) Guru kurang melibatkan siswa dalam proses pembelajaran. Informasi dari guru penyebab dari faktor siswa antara lain; (1) Siswa kurang aktif dan minat dalam pembelajaran matematika, (2) Siswa kurang menyukai pelajaran.

Berdasarkan latar belakang masalah di atas, maka penulis termotivasi untuk melakukan suatu penelitian tindakan kelas tentang penggunaan model pembelajaran kooperatif tipe Numbered Head Togetherdengan judul Meningkatkan Hasil Belajar Siswa Menggunakan Model Pembelajaran Kooperatif Tipe Numbered Head Together Pada Mata Pelajaran Matematika di kelas V SD Negeri 066668 Medan Johor Tahun Ajaran 2016/2017.

\section{LANDASAN TEORI}

Kemampuan yang harus dimiliki guru yang mampu melaksanakan pembelajaran yang efektif adalah memahami tentang bagaimana siswa belajar.Belajar sering diartikan sebagai pemahaman pengetahuan. Djamarah (2011: 13) menyatakan "Belajar adalah suatu kegiatan yang dilakukan dengan melibatkan dua unsur yaitu jiwa dan raga".

Asep Jihad dan Abdul Haris (2013: 1) menyatakan "Belajar adalah kegiatan berproses dan merupakan unsur yang sangat fundamental dalam penyelenggaraan 
jenis dan jenjang pendidikan, hal ini berarti keberhasilan pencapaian tujuan pendidikan sangat tergantung pada keberhasilan proses belajar siswa di sekolah dan lingkungan sekitar".

Berdasarkan pendapat di atas dapat disimpulkan belajar adalah perubahan tingkah laku individu akibat adanya interaksi dengan lingkungannya, perubahan tersebut meliputi sikap, kebiasaan, ilmu pengetahuan dan keterampilan.

\section{Istilah}

pembelajaran

merupakan istilah baru yang digunakan untuk menunjukkan kegiatan guru dan siswa. Sebelumnya menggunakan istilah “ proses belajar mengajar" dan "pengajaran". Istilah pembelajaran merupakan terjemahan dari kata "Intruction".Menurut Sagala (2012:61) "Pembelajaran adalah proses komunikasi dua arah, mengajar dilakukan oleh pihak guru sebagai pendidik, sedangkan belajar dilakukan oleh peserta didik atau murid".Asep Jihad dan Abdul Haris (2013: 11) menyatakan "Pembelajaran merupakan suatu proses yang terdiri dari kombinasi dua aspek, yaitu belajar tertujuh kepada apa yang harus dilakukan oleh siswa, dan mengajar berorintasi pada apa yang harus dilakukan oleh guru sebagai pemberi pelajaran".

Dari pendapat di atas dapat disimpulkan bahwa pembelajaran adalah suatu proses kegiatan yang dilakukan oleh guru sebagai pendidik dan siswa sebagai peserta didik yang menerima materi pelajaran dari diajarkan guru untuk mencapai tujuan tertentu.

Berdasarkan uraian di atas tentang konsep belajar, dapat dipahami tentang makna hasil belajar. Asep Jihad dan Abdul Haris (2013: 14) menyatakan "Hasil belajar adalah pencapaian bentuk perubahan perilaku yang cenderung menetap dari ranah kognitif, afektif, dan psikomotoris dari proses belajar yang dilakukan dalam waktu tertentu". Winkel dalam Purwanto (2014: 45) menyatakan "Hasil belajar adalah perubahan yang mengakibatkan manusia berubah dalam sikap dan tingkah lakunya". Menurut Ahmad Susanto (2016: 5) "Hasil belajar yaitu perubahanperubahan yang terjadi pada diri siswa,baik yang menyangkut aspek kognitif, afektif, dan psikomotor sebagai hasil dari kegiatan belajar". 
Dari beberapa pengertian di atas dapat disimpulkan hasil belajar adalah perubahan tingkah laku siswa pada aspek kognitif, afektif, dan psikomotor setelah kegiatan pembelajaran.

Egen dan Kauchak dalam Trianto (2013: 58) menyatakan "Pembelajaran kooperatif merupakan sebuah kelompok sterategi pengajaran yang melibatkan siswa bekerja secara berkolaborasi untuk mencapai tujuan bersama". Rusman (2014: 202) menyatakan "Pembelajaran kooperatif merupakan bentuk pembelajaran dengan cara siswa belajar dan bekerja dalam kelompok-kelompok kecil secara kolaboratif yang anggotanya terdiri dari empat sampai enam orang dengan struktur kelompok yang bersifat heterogen". Tom V. Savage dalam Rusman (2014: 203) menyatakan "Cooperative learning adalah suatu pendekatan yang menekankan kerja sama dalam kelompok"

Dari beberapa pendapat di atas, dapat disimpulkan model pembelajaran kooperatif adalah model mengajar yang digunakan oleh guru dengan melibatkan siswa dalam proses pembelajaran dengan kelompok-kelompok kecil untuk saling bekerjasama.

Model pembelajaran Numbered Head Together (NHT) merupakan tipe dari pembelajaran kooperatif yang terdiri atas empat tahap yang digunakan untuk mereview fakta-fakta dan informasi dasar yang berfungsi untuk mengatur interaksi siswa.Model pembelajaran ini juga dapat digunakan untuk memecahkan masalah yang tingkat kesulitannya terbatas.

Imas Kurniasih dan Berlin Sani (2015: 117) menyatakan bahwa "Model pembelajaran kooperatif tipe Numbered Head Together (NHT) adalah sebuah strategi pembelajaran yang mengutamakan adanya kerjasama antar siswa dalam kelompok untuk mencapai tujuan pembelajaran".

Dari pendapat di atas, dapat disimpulkan model pembelajaran kooperatif tipe Numbered Head Together (NHT) adalah tipe pembelajaran kooperatif yang mengutamakan kerjasama atau kelompok yang setiap anggota kelompok harus bertanggung jawab atas kelompoknya sehingga di dalam pembelajaran terjadi diskusi kelompok maupun individual 
sehingga tercapailah tujuan pembelajaran.

Penelitian tindakan kelas yang disingkat dengan istilah PTK (dalam bahasa inggris disebut Classroom Action Research, disingkat CAR).Dalam PTK guru memberikan tindakan kepada siswa.

Menurut Kemmis dan McTaggart dalam Sukardi (2013: 3) "Penelitian tindakan adalah cara suatu kelompok atau seseorang dalam menggorganisasi sebuah kondisi di mana mereka dapat mempelajari pengalaman mereka dan membuat pengalaman mereka dapat diakses orang lain".

\section{Arikunto,dkk (2015: 194)} menyatakan "Penelitian Tindakan Kelas sebagai suatu bentuk investigasi yang bersifat reflektif partisipatif, kolaboratif dan spiral, yang memiliki untuk penerapan tindakan dan melakukan refleksi, dan seterusnya sampai dengan perbaikan atau peningkatan yang diharapkan tercapai (kriteria keberhasilan)".

Dari pendapat di atas dapat disimpulkan Penelitian Tindakan Kelas merupakan usaha yang dilakukan oleh guru untuk melihat dan mengatasi kekurangan dalam proses belajar mengajar di dalam kelasnya.

Hakikat
matematika adalah proses yang
sengaja di rancang dengan tujuan
untuk menciptakan suasana
lingkungan yang memungkinkan
seseorang (pelajar) melaksanakan
kegiatan belajar matematika.

Pembelajaran matematika juga harus memberikan peluang kepada siswa untuk berusaha dan mencari pengalaman tentang matematika. Seorang guru di SD yang akanmengajarkan matematika kepada para siswanya, berusaha mengetahui objek yang akan diajarkan yaitu matematika.

Istilah matematika berasal dari bahasa Yunani, "mathein" atau "mathenien" yang artinya mempelajari.Perkataan itu mempunyai asal katanya mathema yang berarti pengetahuan atau ilmu (knowledge, science). Kata mathematike berhubungan pula dengan kata lainnya yang hampir sama, yaitu matheinhenein yang artinya belajar (berpikir), matematika lebih menekankan kegiatan dalam dunia rasio (penalaran), bukan menekankan dari hasil eksperimen atau hasil observasi, matematika 
terbentuk karena pikiran-pikiran manusia, yang berhubungan dengan ide, proses dan penalaran.

\section{a. Pengertian Pecahan}

Pada mata pelajaran matematika, pecahan merupakan materi yang di ajarkan di kelas $\mathrm{V}$ $\mathrm{SD}$, pecahan merupakan bagian dari bilangan rasional.Pecahan merupakan bilangan rasional yang dapat ditulis dalam bentuk $\frac{a}{b}$ dengan $\mathrm{a}$ dan $\mathrm{b}$ adalah bilangan bulat, $\mathrm{b} \neq 0$, dan $\mathrm{b}$ bukan faktor dari a. bilangan a disebut sebagai pembilang dan bilangan $b$ disebut sebagai penyebut.Namun untuk penelitian ini dibatasi pada pembagian pecahan biasa dan pecahan campuran.

\section{b. Pengertian Pecahan Biasa dan}

\section{Campuran}

Bilangan pecahan biasa yang sering disebut sebagai bilangan pecahan itu sendiri, yaitu bilangan yang dapat dinyatakan dalam bentuk , dengan a dan $b$ adalah bilangan bulat dan $b \neq 0$. Bilangan a disebut sebagai pembilang dan bilangan $b$ disebut sebagai penyebut.

Contoh bilangan pecahan biasa : : $\frac{1}{2}, \frac{3}{4}, \frac{1}{4}, \frac{3}{6}$ dan lainnya.
Bilangan pecahan campuran adalah bilangan yang terdiri dari bilangan bulat dan bilangan pecahan biasa.

Contoh bilangan pecahan campuran: $3 \frac{1}{2}, 5 \frac{1}{4}, 4 \frac{3}{4}$ dan lainnya.

\section{B. Kerangka Berpikir}

Kurikulum yang berlaku saat ini tidak adanya keharusan bagi siswa untuk menguasai materi secara sepenuhnya yaitu lebih mengarahkan pemahaman dan penerapan pengetahuan.Menjadi prioritas utama bagi siswa.Hal inilah menjadikan guru untuk lebih profesional dalam merencanakan dan menyelenggarakan peroses pembelajaran supaya materi dapat tersampaikan kepada siswa.

Keaktifan dan minat belajar siswa pada pembelajaran matematika masih rendah. Rendahnya keaktifan dan minat belajar siswa tentunya dapat mempengaruhi hasil belajar siswa, jika keaktifan dan minat belajar siswa rendah maka hasil belajar juga akan kurang maksimal. Kurang maksimalnya hasil belajar siswa disebabkan oleh beberapa faktor penyebab, yaitu proses pembelajaran masih didominasi oleh 
guru, dalam proses pembelajaran guru masih menggunakan model pembelajaran yang kurang bervariasi dan guru kurang melibatkan siswa dalam proses pembelajaran. Berdasarkan hal tersebut, siswa merasa sulit dan bosan serta kurang menyukai pembelajaran matematika dan siswa kurang aktif dan minat dalam pembelajaran matematika.

Untuk meningkatkan hasil belajar siswa diperlukan model pembelajaran yang dapat mengaktifkan siwa dalam belajar dan sesuai dengan materi yang diajarkan.Maka guru harus menggunakan model pembelajaran yang tepat.Model pembelajaran yang dapat digunakan yaitu model pembelajaran kooperatif tipe Numbered Head Together (NHT).Model pembelajaran NHT adalah suatu model pembelajaran yang membuat siswa lebih aktif. Dalam model pembelajaran NHT siswa akan dibagi kedalam kelompok yang heterogen. Di dalam kelompok setiap anggota kelompoknya harus bertanggung jawab dan saling membantu temannya untuk saling mengerti dengan materi yang diberikan. Sehingga dapat mengaktifkan siswa dalam pelaksanaan proses pembelajaran.

Penggunaan model pembelajaran kooperatif tipe Numbered Head Together lebih mendorong kemandirian, keaktifan, dan tanggung jawab dalam diri siswa. Dalam pelaksanaan proses pembelajaran siswa lebih banyak berperan sehingga meningkatkan keaktifan dan minat siwa dalam belajar matematika,dan pada akhirnya dapat meningkatkan hasil belajar siswa.

\section{Hipotesis Tindakan}

Atas dasar kerangka berpikir yang di kemukakan di atas, maka dapat diajukan hipotesis tindakan yaitu Hasil belajar siswa meningkat setelah menggunakan model pembelajaran kooperatif tipe Numbered Head Together pada mata pelajaran matematika materi pembagian pecahan biasa dengan pecahan campuran di kelas V SD Negeri 066668 Medan Johor Tahun Ajaran 2016/2017. 


\section{Defenisi Operasional}

1. Belajar adalah perubahan tingkah laku individu akibat adanya interaksi dengan lingkungannya, perubahan tersebut meliputi sikap, kebiasaan, ilmu pengetahuan dan keterampilan.

2. Mengajar adalah kegiatan atau aktivitas yang dilakukan oleh guru untuk memberikan, mendorong, dan membimbing siswa dalam penyampaian pelajaran atau informasi agar siswa memperoleh pengetahuan, keterampilan, sikap, serta ide dan perubahan tingkah laku.

3. Pembelajaran adalah suatu proses kegiatan yang dilakukan oleh guru sebagai pendidik dan siswa sebagai peserta didik yang menerima materi pelajaran dari diajarkan guru untuk mencapai tujuan tertentu.

4. Hasil belajar adalah hasil belajar siswa yang diperoleh setelah melakukan proses pembelajaran menggunakan model pembelajaran kooperatif tipe Numbered Head Together pada mata pelajaran matematika materi pembagian pecahan biasa dengan pecahan campuran.
5. Model pembelajaran adalah suatu pola yang digunakan sebagai pedoman bagi guru untuk menyampaikan materi pelajaran dalam pelaksanaan pembelajaran sehingga akan membantu siswa untuk menerima dan mengerti apa yang diajarkan oleh guru di dalam proses pembelajaran yang berlangsung di dalam kelas.

6. Model pembelajaran kooperatif adalah model mengajar yang digunakan oleh guru dengan melibatkan siswa dalam proses pembelajaran dengan kelompokkelompok kecil untuk saling bekerjasama.

7. Model Pembelajaran Kooperatif tipe Numbered Head Together (NHT) adalah tipe pembelajaran kooperatif yang mengutamakan kerjasama atau kelompok yang setiap anggota kelompok harus bertanggung jawab atas kelompoknya sehingga di dalam pembelajaran terjadi diskusi kelompok maupun individual sehingga tercapailah tujuan pembelajaran.

8. Penelitian Tindakan Kelas merupakan usaha yang dilakukan oleh guru untuk melihat dan mengatasi kekurangan dalam 
proses belajar mengajar di dalam kelasnya.

\section{HASIL PENELITIAN DAN PEMBAHASAN}

\section{A. Deskripsi Pelaksanaan}

\section{Penelitian}

Penelitian yang dilakukan berbentuk penelitian tindakan kelas yang dilaksanakan di SD Negeri 066668 Medan Johor pada semester genap Tahun Ajaran 2016/2017, dengan tujuan untuk memperbaiki pembelajaran dan meningkatkan hasil belajar siswa pada mata pelajaran matematika materi pembagian pecahan biasa dengan pecahan campuran dengan menggunakan model pembelajaran kooperatif tipe Numbered Head Together di kelas $\mathrm{V}$ dengan jumlah siswa 40. Penelitian yang terdiri dari siklus I dan siklus II dengan alokasi waktu tiap pertemuan $2 \times 35$ menit, selama proses pelaksanaan pembelajaran dilakukan observasi yang dilakukan oleh guru kelas $\mathrm{V}$ yang meliputi aktivitas guru dan aktivitas siswa.

Pelaksanaan siklus I dilakukan pada hari Senin tanggal 16 Januari 2017 diawali dengan memberikan salam kepada siswa, memimpin siswa berdo'a sebelum memulai pembelajaran, mengingatkan kembali materi pembagian pecahan biasa dengan pecahan campuran, menyampaikan tujuan pembelajaran selama 4,05 menit. Kemudian dilanjutkan dengan kegiatan inti dengan waktu 53 menit yang terdiri dari membagi kelompok belajar kepada siswa, memberi nomor kepada setiap anggota kelompok, membagi buku siswa dan menjelaskan materi pembagian pecahan biasa dengan pecahan campuran, membagikan LKS untuk dikerjakan setiap kelompok, menunjuk salah satu nomor siswa dalamkelompoknya untuk mempersentasikan hasil diskusi kelompok, memberi kesempatan kepada kelompok lain untuk memberi tanggapan, memberi kesempatan kepada siswa tentang hal yang belum dipahami, dan bersama siswa merangkum materi pembelajaran. Kemudian kegiatan akhir dengan waktu 12,05 menit yang terdiri dari memberikan tes berbentuk essay sebanyak 4 soal untuk dikerjakan siswa. Setelah selesai mengerjakan tes hasil belajar, peneliti menutup pelajaran dengan 
berdo'a dan mengucapkan salam penutup kepada siswa.

Setelah selesai melaksanakan pembelajaran siklus I diperoleh hasil pelaksanaan pembelajaran aktivitas guru dan aktivitas siswa dalam kriteria cukup, dan hasil belajar siswa belum mencapai ketuntasan klasikal. Setelah melaksanakan siklus I ternyata ada kekurangan pada pelaksanaan pembelajaran aktivitas guru ada 5 aspek antara lain; (1) Kurang mengadakan apersepsi dan motivasi, (2) Kurang memberi penjelasan dengan bahasa yang sederhana dan jelas, (3) Kurang melaksanakan pembelajaran sesuai dengan urutan dan uraian mengenai inti pembelajaran, (4) Kurang pengunaan alokasi waktu sesuai dengan rencana pelaksanaan pembelajaran (RPP), (5) Kurang menyampaikan materi sesuai dengan langkah-langkah model pembelajaran kooperatif tipe Numbered HeadTogether, dan pelaksanaan pembelajaran aktivitas siswa ada 6 aspek antara lain; (1) Siswa kurang mendengarkan penjelasan guru, (2) Siswa kurang memperhatikan dan mencatat penjelasan guru, (3) Siswa kurang aktif dalam kelompok, (4) Siswa kurang bekerja sama dalam kelompok, (5) Siswa kurang aktif dalam menanggapi presentasi kelompok, (6) Peningkatan aktivitas belajar.

Pelaksanaan siklus II dilakukan pada hari Rabu tanggal 25 Januari 2017 dan pada setiap pembelajaran peneliti berusaha meningkatkan aspek-aspek pada siklus I yaitu pelaksanaan pembelajaran aktivitas guru di antaranya: (1) Sebelum melakukan pembelajaran peneliti melakukan apersepsi dan motivasi agar siswa semangat untuk memulai pelajaran, (2) Memberikan penjelasan dengan bahasa yang sederhana dan bisa dipahami siswa, (3) Telah melaksanakan pembelajaran disesuaikan dengan urutan dan uraian kegiatan inti pembelajaran, (4) dan sesuai dengan alokasi waktu Rencana Pelaksanaan Pembelajaran (RPP), (5) Peneliti juga telah menyampaikan materi pembelajaran sesuai dengan langkah-langkah model pembelajaran. Kemudian pelaksanaan pembelajaran aktivitas siswa di antaranya: (1) Membuat siswa kosentrasi untuk mendengarkan penjelasan guru dengan memberikan motivasi atau 
bercerita kepada siswa

sebelum memulai pelajaran, (2)

Ketenangan di dalam kelas akan membuat siswa memperhatikan dan mencatat penjelasan guru,

Keaktifan dan bekerjasama dalam kelompok dengan mengerjakan soal secara bergantian dan berdiskusi tentang jawaban yang diperoleh, (4) Dengan memberi permen kepada setiap siswa yang menanggapi hasil presentasi kelompok, (5) Setiap siswa yang berani bertanya akan di berikan hadiah hal ini membuat aktivitas siswa menjadi meningkat. Setelah siklus II selesai dilaksanakan, diperoleh hasil pelaksanaan pembelajaran aktivitas guru dan siswa sudah mengalami peningkatan dan telah mencapai kriteria baik dan hasil belajar siswa juga sudah tuntas secara klasikal, maka penelitian tidak dilanjutkan pada siklus III.

\section{B. Deskripsi Data Hasil Penelitian}

Data hasil penelitian setelah dilaksanakan siklus I dan siklus II pada mata pelajaran matematika materi pembagian pecahan biasa dengan pecahan campuran di kelas $\mathrm{V}$ SD Negeri 066668 Medan Johor dengan menggunakan model pembelajaran kooperatif tipe
Numbered Head Together sebagai berikut: (1) Pelaksanaan pembelajaran aktivitas guru dan siswa siklus I, (2) Ketuntasan hasil belajar siswa siklus I, (3) Rata-rata hasil belajar siklus I, (4) Pelaksanaan pembelajaran aktivitas guru dan siswa siklus II, (5) Ketuntasan hasil belajar siswa siklus II, (6) Rata-rata hasil belajar siklus II, (7) Pelaksanaan pembelajaran aktivitas guru siklus I dan siklus II, (8) Pelaksanaan pembelajaran aktivitas siswa siklus I dan siklus II, (9) Ketuntasan hasil belajar siswa siklus I dan siklus II, (10) Rata-rata hasil belajar siklus I dan siklus II. Deskripsi data diuraikan sebagai berikut:

\section{Pelaksanan}

\section{Pembelajaran}

\section{Aktivitas Guru dan Siswa Siklus I}

Pelaksanaan pembelajaran dilakukan observasi oleh guru kelas V SD Negeri 066668 Medan Johor.Observasi dilakukan pada awal pelaksanaan pembelajaran sampai akhir pelaksanaan pembelajaran. Hasil observasi pelaksanaan pembelajaran aktivitas guru dan siswa pada siklus I disajikan pada Tabel 4.1 dan Tabel 4.2 berikut: 
Tabel 4.1 Pelaksanan Pembelajaran Aktivitas Guru Pada Siklus I

\begin{tabular}{|c|c|c|}
\hline NO & $\begin{array}{l}\text { ASPEK YANG } \\
\text { DIOBSERVASI }\end{array}$ & Skor \\
\hline 1 & $\begin{array}{l}\text { Mengadakan apersepsi dan } \\
\text { motivasi }\end{array}$ & 55 \\
\hline 2 & $\begin{array}{l}\text { Menyampaikan topik dan } \\
\text { tujuan pembelajaran }\end{array}$ & 73 \\
\hline 3 & $\begin{array}{l}\text { Memberikan penjelasan } \\
\text { dengan bahasa yang } \\
\text { sederhana dan jelas }\end{array}$ & 55 \\
\hline 4 & $\begin{array}{l}\text { Melaksanakan pembelajaran } \\
\text { sesuai dengan urutan dan } \\
\text { uraian mengenai kegiatan inti } \\
\text { pembelajaran }\end{array}$ & 48 \\
\hline 5 & $\begin{array}{l}\text { Penggunaan alokasi waktu } \\
\text { sesuai dengan rencana } \\
\text { pelaksanaan pembelajaran } \\
\text { (RPP) }\end{array}$ & 55 \\
\hline 6 & $\begin{array}{l}\text { Memberi buku ajar dan LKS } \\
\text { untuk di diskusikan dalam } \\
\text { kelompok }\end{array}$ & 64 \\
\hline 7 & Pembagian Kelompok & 64 \\
\hline 8 & $\begin{array}{l}\text { Menyampaikan materi sesuai } \\
\text { dengan langkah-langkah } \\
\text { model pembelajaran } \\
\text { Kooperatif Tipe Numbered } \\
\text { Head Together }\end{array}$ & 57 \\
\hline 9 & $\begin{array}{l}\text { Membimbing dan } \\
\text { mengarahkan pelaksanaan } \\
\text { diskusi }\end{array}$ & 62 \\
\hline
\end{tabular}




\begin{tabular}{|c|l|c|}
\hline 10 & $\begin{array}{l}\text { Merangkum materi } \\
\text { pembelajaran }\end{array}$ & 61 \\
\hline 11 & Mengadakan evaluasi & 62 \\
\hline & Jumlah & $\mathbf{6 5 6}$ \\
\hline \multirow{2}{*}{ Hasil Pengamatan } & $\mathbf{5 9 , 6 9 \%}$ \\
\hline & Kriteria & Cukup \\
\hline
\end{tabular}

Dengan rumus :

$H P=\frac{\text { Skor Yang DiperolehBerdasarkan }}{\text { Jumlah Butir Pernyataal }}$

$H P=\frac{656}{11}$

$=59,69 \%$
Hasil data observasi guru dikonfersi dengan kriteria Piet A Sahertian (2010: 60) :

\begin{tabular}{|c|c|}
\hline $\begin{array}{l}\text { Kriteria } \\
\text { Penilaian }\end{array}$ & Keterangan \\
\hline $\begin{array}{l}A=81- \\
100 \%\end{array}$ & Baik Sekali \\
\hline $\begin{array}{l}B=61- \\
80 \%\end{array}$ & Baik \\
\hline $\begin{array}{l}C=41- \\
60 \%\end{array}$ & Cukup \\
\hline $\begin{array}{l}\mathrm{D}=21- \\
40 \%\end{array}$ & Kurang \\
\hline$E=0-20 \%$ & $\begin{array}{l}\text { Sangat } \\
\text { Kurang }\end{array}$ \\
\hline
\end{tabular}


Tabel 4.2 Pelaksanaan Pembelajaran Aktivitas Siswa Pada Siklus I

\begin{tabular}{|c|l|c|}
\hline NO & ASPEK YANG DINILAI & Nilai \\
\hline 1 & Kesiapan menerima pelajaran & 4 \\
\hline 2 & Kesenangan Belajar & 4 \\
\hline 3 & $\begin{array}{l}\text { Mendengarkan penjelasan } \\
\text { guru }\end{array}$ & 3 \\
\hline 4 & $\begin{array}{l}\text { Memperhatikan dan mencatat } \\
\text { penjelasan guru }\end{array}$ & 3 \\
\hline 5 & Ketenangan kelas saat belajar & 4 \\
\hline 6 & Keaktifan dalam kelompok & 3 \\
\hline 7 & $\begin{array}{l}\text { Bekerjasama dalam } \\
\text { kelompok }\end{array}$ & 3 \\
\hline 8 & $\begin{array}{l}\text { Keaktifan dalam menanggapi } \\
\text { presentasi kelompok }\end{array}$ & 3 \\
\hline 9 & Peningkatan aktivitas belajar & 3 \\
\hline 10 & Mengerjakan tes dengan baik & 4 \\
\hline & Jumlah & $\mathbf{3 4}$ \\
\hline & $\mathbf{6 8}$ \\
\hline
\end{tabular}

Dengan rumus:

Nilai siswa $=\frac{\text { Skor perolehan }}{\text { Skor maksimum }} \times 100$

Nilai Siswa $=\frac{34}{50} \times 100$

$$
=68
$$

Hasil data observasi siswa dikonfersi dengan kriteria Asep Jihad dan Abdul Haris (2013: 130) yaitu: 


\begin{tabular}{|l|l|}
\hline \multicolumn{1}{|c|}{ Kriteria Penilaian } & \multicolumn{1}{c|}{ Keterangan } \\
\hline $1=10-29$ & Sangat Kurang \\
\hline $2=30-49$ & Kurang \\
\hline $3=50-69$ & Cukup \\
\hline $4=70-89$ & Baik \\
\hline $5=90-100$ & Sangat Baik \\
\hline
\end{tabular}

Berdasarkan Tabel 4.1 dan

Tabel 4.2 skor yang diperoleh pada aktivitas guru $59,69 \%$ dan aktivitas siswa adalah 68 yang masing-masing termasuk dalam kriteria cukup. Sehingga dapat dinyatakan bahwa pelaksanaan pembelajaran masih harus diperbaiki.

\section{Ketuntasan Hasil Belajar Siswa}

\section{Siklus I}

Hasil ketuntasan belajar siswa diketahui dari nilai ketuntasan belajar secara individu dan klasikal. Ketuntasan hasil belajar siswa pada siklus I disajikan pada Tabel 4.3 dan Tabel 4.4 berikut :

Tabel 4.3 Ketuntasan Hasil Belajar Siswa Secara Individu Siklus I

\begin{tabular}{|c|l|c|c|c|c|}
\hline No & \multicolumn{1}{|c|}{ Nama } & $\mathrm{T}$ & $\mathrm{Tt}$ & $\mathrm{KB}$ & Keterangan \\
\hline 1 & Deni Armita & 62 & 75 & 82.67 & Tuntas \\
\hline 2 & Agung Setiawan & 60 & 75 & 80.00 & Tuntas \\
\hline 3 & $\begin{array}{l}\text { Rifki Al } \\
\text { maghribi }\end{array}$ & 60 & 75 & 80.00 & Tuntas \\
\hline 4 & Astri Rahayu & 60 & 75 & 80.00 & Tuntas \\
\hline 5 & Abdul Manaf & 55 & 75 & 73.33 & Tuntas \\
\hline 6 & $\begin{array}{l}\text { Ummu } \\
\text { Nurhabibah }\end{array}$ & 56 & 75 & 74.67 & Tuntas \\
\hline 7 & Refi Ristika & 58 & 75 & 77.33 & Tuntas \\
\hline 8 & $\begin{array}{l}\text { Yamelia } \\
\text { Sitanggang }\end{array}$ & 57 & 75 & 76.00 & Tuntas \\
\hline 9 & $\begin{array}{l}\text { Angger } \\
\text { Wicaksono }\end{array}$ & 55 & 75 & 73.33 & Tuntas \\
\hline 10 & Aditya & 56 & 75 & 74.67 & Tuntas \\
\hline
\end{tabular}




\begin{tabular}{|c|c|c|c|c|c|}
\hline & Setyawan & & & & \\
\hline 11 & Dinda Aulia & 55 & 75 & 73.33 & Tuntas \\
\hline 12 & Nabila rahmah & 57 & 75 & 76.00 & Tuntas \\
\hline 13 & Abdul Maulana & 53 & 75 & 70.67 & Tuntas \\
\hline 14 & Rahma Tiarani & 55 & 75 & 73.33 & Tuntas \\
\hline 15 & Ananda Juliata & 54 & 75 & 72.00 & Tuntas \\
\hline 16 & Rendy Agus & 53 & 75 & 70.67 & Tuntas \\
\hline 17 & Tria Ardana & 54 & 75 & 72.00 & Tuntas \\
\hline 18 & Nabila Putri & 53 & 75 & 70.67 & Tuntas \\
\hline 19 & May Dafri & 53 & 75 & 70.67 & Tuntas \\
\hline 20 & Ahmat Sayuti & 54 & 75 & 72.00 & Tuntas \\
\hline 21 & Nur Siti Aisyah & 54 & 75 & 72.00 & Tuntas \\
\hline 22 & Novita Permata & 53 & 75 & 70.67 & Tuntas \\
\hline 23 & M Algi Ananda & 53 & 75 & 70.67 & Tuntas \\
\hline 24 & Nurvidiana & 54 & 75 & 72.00 & Tuntas \\
\hline 25 & M Rafi & 53 & 75 & 70.67 & Tuntas \\
\hline 26 & Dio Putra & 54 & 75 & 72.00 & Tuntas \\
\hline 27 & Ella Fazira & 53 & 75 & 70.67 & Tuntas \\
\hline 28 & Khairunnisa & 50 & 75 & 66.67 & $\begin{array}{l}\text { Tidak } \\
\text { Tuntas }\end{array}$ \\
\hline 29 & M Dimas & 50 & 75 & 66.67 & $\begin{array}{l}\text { Tidak } \\
\text { Tuntas }\end{array}$ \\
\hline 30 & Claudia & 48 & 75 & 64.00 & $\begin{array}{l}\text { Tidak } \\
\text { Tuntas }\end{array}$ \\
\hline 31 & Reza Syahputra & 48 & 75 & 64.00 & $\begin{array}{l}\text { Tidak } \\
\text { Tuntas }\end{array}$ \\
\hline 32 & Edo Kristian & 46 & 75 & 61.33 & $\begin{array}{l}\text { Tidak } \\
\text { Tuntas }\end{array}$ \\
\hline 33 & Yuda Ananda & 47 & 75 & 62.67 & $\begin{array}{l}\text { Tidak } \\
\text { Tuntas }\end{array}$ \\
\hline 34 & Nur Azizah & 45 & 75 & 60.00 & $\begin{array}{l}\text { Tidak } \\
\text { Tuntas }\end{array}$ \\
\hline
\end{tabular}




\begin{tabular}{|c|l|c|c|c|c|}
\hline 35 & Haqwa Nabila & 45 & 75 & 60.00 & $\begin{array}{c}\text { Tidak } \\
\text { Tuntas }\end{array}$ \\
\hline 36 & M Azmi & 42 & 75 & 56.00 & $\begin{array}{c}\text { Tidak } \\
\text { Tuntas }\end{array}$ \\
\hline 37 & Maulana Hakim & 42 & 75 & 56.00 & $\begin{array}{c}\text { Tidak } \\
\text { Tuntas }\end{array}$ \\
\hline 38 & $\begin{array}{l}\text { Dimas } \\
\text { Syahputra }\end{array}$ & 41 & 75 & 54.67 & $\begin{array}{c}\text { Tidak } \\
\text { Tuntas }\end{array}$ \\
\hline 40 & M Tito & 41 & 75 & 54.67 & $\begin{array}{c}\text { Tidak } \\
\text { Tuntas }\end{array}$ \\
\hline
\end{tabular}

Tabel 4.4 Ketuntasan Hasil Belajar Siswa Secara Klasikal Siklus I

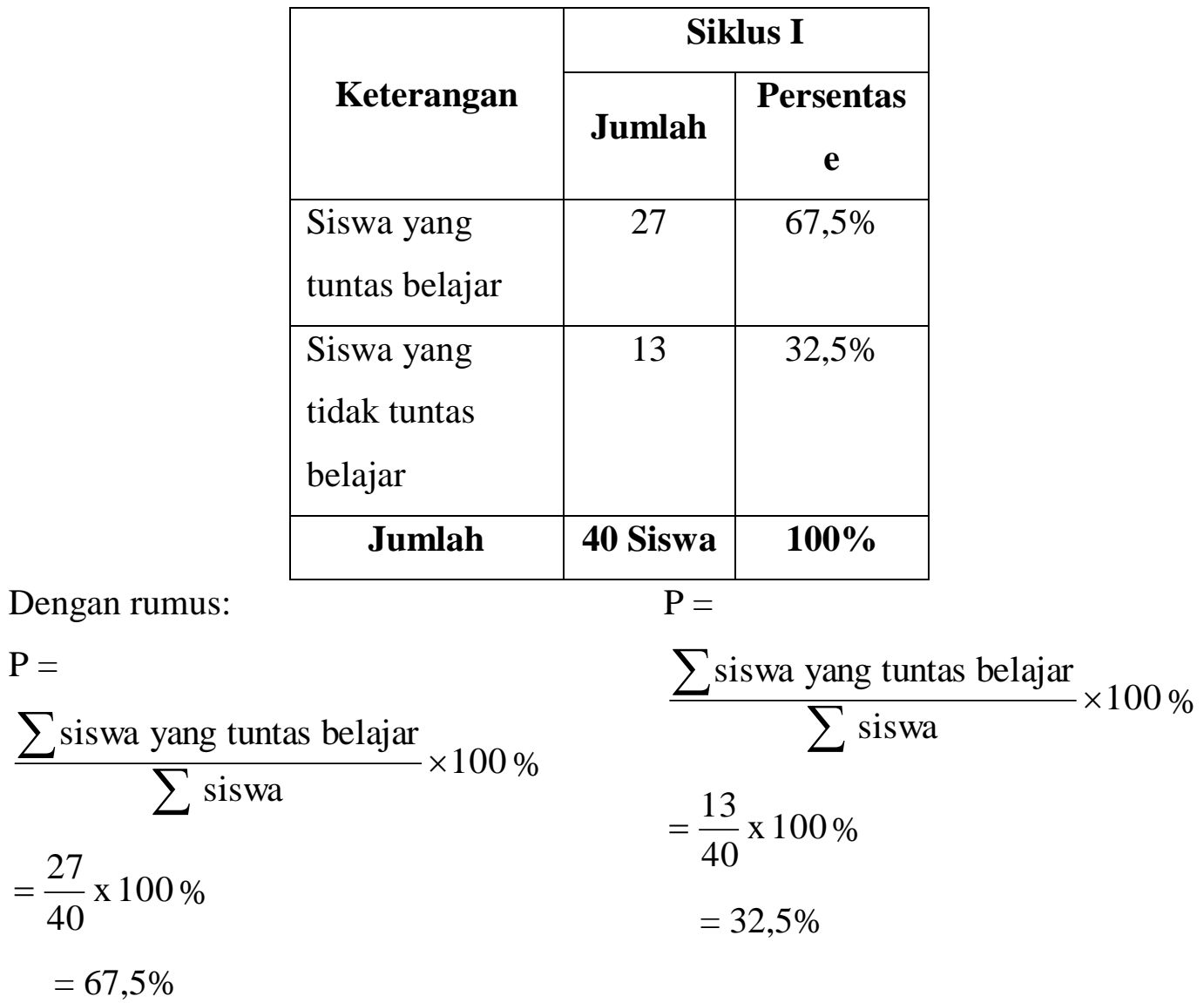


Berdasarkan Tabel $4.4 \quad$ belum mencapai nilai KKM dengan sebanyak 27 siswa dari 40 siswa yang tuntas $(67,5 \%)$ dan 13 siswa yang tidak tuntas $(32,5 \%)$ secara individu. Dapat di simpulkan bahwa pembelajaran pada siklus I belum tuntas secara klasikal, karena jumlah siswa yang tuntas secara individu belum melewati syarat ketuntasan secara klasikal ( $\geq 85 \%$ dari total siswa).

\section{Pembahasan Hasil Penelitian}

Berdasarkan hasil penelitian yang telah dilaksanakan di SD Negeri 066668 Medan Johor Tahun Ajaran 2016/2017 di kelas V sebanyak 40 siswa yang mengikuti Penelitian Tindakan Kelas (PTK) dengan mengggunakan model pembelajaran Numbered Head Together materi pembagian pecahan biasa dengan pecahan campuran untuk meningkatkan hasil belajar siswa.

Dari data yang diperoleh pada pelaksanaan siklus I, diperoleh hasil pelaksanaan pembelajaran aktivitas guru $59,69 \%$ dan pelaksanaan pembelajaran aktivitas siswa 68 dalam kriteria cukup, dan nilai hasil belajar siswa yang mencapai nilai KKM ada 27 siswa $(67,5 \%)$ dan 13 siswa $(32,5 \%)$ yang 
Untuk memperbaiki

kekurangan

pelaksanaan

pembelajaran pada siklus I peneliti melakukan perbaikan di siklus II dengan meningkatkan aspek-aspek pelaksanaan pembelajaran aktivitas guru di antaranya: (1) Sebelum melakukan pembelajaran peneliti melakukan apersepsi dan motivasi agar siswa semangat untuk memulai pelajaran, (2) Memberikan penjelasan dengan bahasa yang sederhana dan bisa dipahami siswa, Telah melaksanakan pembelajaran disesuaikan dengan urutan dan uraian kegiatan inti pembelajaran, (4) dan sesuai dengan alokasi waktu Rencana Pelaksanaan Pembelajaran (RPP), (5) Peneliti juga telah menyampaikan materi pembelajaran sesuai dengan langkahlangkah model pembelajaran. Kemudian pelaksanaan pembelajaran aktivitas siswa di antaranya: (1) Membuat siswa kosentrasi untuk mendengarkan penjelasan guru dengan memberikan motivasi atau bercerita kepada siswa sebelum memulai pelajaran, (2) Ketenangan di dalam kelas akan membuat siswa memperhatikan dan mencatat penjelasan guru, (3) Keaktifan dan bekerjasama dalam kelompok denganmengerjakan soal secara bergantian dan berdiskusi tentang jawaban yang diperoleh, (4) Dengan memberi permen kepada setiap siswa yang menanggapi hasil presentasi kelompok, (5) Setiap siswa yang berani bertanya akan di berikan hadiah hal ini membuat aktivitas siswa menjadi meningkat. Setelah dilaksanakan perbaikan pada siklus II, diperoleh hasil pelaksanaan pembelajaran aktivitas guru dengan persentase $72,45 \%$ dalam kriteria baik dan hasil aktivitas siswa diperoleh nilai 88 dalam kriteria baik. Demikian pula dengan jumlah siswa yang tuntas hasil belajarnya sebanyak 35 siswa atau $87,5 \%$ sedangkan yang belum tuntas sebanyak 5 siswa atau 12,5\%, hal ini sudah sesuai dengan kriteria ketuntasan klasikal yakni terdapat $\geq$ $85 \%$ siswa dalam satu kelas telah tuntas belajarnya yang telah mencapai nilai KKM sekolah yaitu 70 , dengan rata-rata hasil belajar siswa sudah maksimal yaitu 74,45.

$$
\text { Permasalahan pelaksanaan }
$$
pembelajaran dan hasil belajar siswa dapat di perbaiki di siklus II, maka perbaikan pembelajaran tidak perlu dilanjutkan yaitu pada siklus III.Hasil penelitian dapat 
disimpulkan bahwa hasil belajar siswa meningkat setelah menggunakan model pembelajaran kooperatif tipe Numbered Head Together pada mata pelajaran matematika materi pembagian pecahan biasa dengan pecahan campuran di kelas V SD Negeri 066668 Medan Johor Tahun Ajaran 2016/2017.

\section{SIMPULAN DAN SARAN}

\section{A. Simpulan}

Berdasarkan hasil pembahasan dan data penelitian yang telah dilaksanakan di kelas V SD Negeri 066668 Medan Johor Tahun Ajaran 2016/2017, maka dalam hal ini peneliti membuat kesimpulan sebagai berikut :

1. Pelaksanaan penelitian dengan menggunakan model pembelajaran kooperatif tipe Numbered Head Togetherpada mata pelajaran matematika materi pembagian pecahan biasa dengan pecahan campuran di kelas $\mathrm{V}$ berkriteria baik dengan peningkatan dari siklus I ke siklus II pada aktivitas guru $21,38 \%$ dan aktivitas siswa $29,41 \%$.
2. Hasil belajar siswa meningkat setelah menggunakan model pembelajaran kooperatif tipe Numbered Head Together pada mata pelajaran matematika materi pembagian pecahan biasa dengan pecahan campuran dengan peningkatan siklus I ke siklus II 7,22\% dan dinyatakan tuntas secara klasikal karena telah $85 \%$ siswa di dalam kelas yang mencapai nilai KKM.

\section{B. Saran}

Berdasarkan kesimpulan tersebut, maka peneliti dapat memberikan beberapa saran sebagai berikut :

1. Bagi Sekolah, diharapkan model pembelajaran kooperatif tipe Numbered Head Together dapat meningkatkan hasil belajar siswa khususnya dalam mengajar materi pembagian pecahan biasa dengan pecahan campuran.

2. Bagi Guru, diharapkan model pembelajaran kooperatif tipe Numbered Head Together menjadi satu alternatif untuk meningkatkan hasil belajar siswa.

3. Bagi Siswa, diharapkan lebih termotivasi belajar khususnya 
pada mata pelajaran matematika dengan menggunakan model pembelajaran kooperatif tipe Numbered Head Together siswa dapat lebih memahami pelajaran yang disampaikan.

4. Bagi Peneliti, diharapkan semakin menambah wawasan ilmu pengetahuan tentang penerapan model pembelajaran yang tepat.

\section{DAFTAR PUSTAKA}

Ahmad Susanto. 2016. Teori Belajar

Dan Pembelajaran Di

Sekolah Dasar. Jakarta: Prenada Media Group.

Aqib, Zainal, dkk. 2010. Penelitian

Tindakan Kelas. Bandung: CV Yrama Widya.

Arikunto, Suharsimi, dkk. 2015. Penelitian Tindakan Kelas. Jakarta: PT Bumi Aksara.

Aris Shoimin. 2014. 68 Model Pembelajaran Inovatif dalam Kurikulum 2013. Yogyakarta: Ar-Ruzz Media.
Asep Jihad dan Abdul Haris. 2013. Evaluasi Pembelajaran. Yogyakarta: Multi Pressindo.

Djamarah, Syaiful Bahri. 2011. Psikologi Belajar. Jakarta: Rineka Cipta.

Djamarah, Syaiful Bahri dan Aswan Zain. 2014. Strategi Belajar Mengajar. Jakarta: Rineka Cipta.

Imas Kurniasih dan Berlin Sani.2015. Ragam

Pengembangan Model

Pembelajaran Untuk

Peningkatan

Profesionalitas Guru.

Jakarta: Kata Pena

Istarani. 2012. 58 Model Pembelajaran Inovasi. Medan: Media Persada.

Kunandar.2013. Langkah Mudah Penelitian Tindakan Kelas Sebagai Pengembangan Profesi Guru. Jakarta: Rajawali Pers.

Pambudi.2011. Hakekat Matematika dan Pembelajaran.diakses pada tanggal 19 Oktober 2016 jam 20:21 http: // 
Pambudi. blogspot. co. id / 2011 / 09 / hakekat matematika - dan pembelajaran.

Purba, Aprino. 2016. Meningkatkan Hasil Belajar Siswa Menggunakan Model Pembelajaran Kooperatif Tipe Numbered Head Together pada Mata pelajaran Matematika di kelas IV SD Negeri 104213 Delitua Tahun Pelajaran 2015/2016. Medan: Skripsi Universitas Quality.

Purwanto. 2014. Evaluasi Hasil Belajar. Yogyakarta: Pustaka Belajar.

Rusman. 2014. Model-model Pembelajaran. Jakarta: PT Rajagrafindo Persada.

Sagala, Syaiful. 2012. Konsep dan Makna Pembelajaran. Bandung: Alfabeta.
Sahertian, A Piet. 2010. Konsep Dasar dan Teknik Supervisi Pendidikan. Jakarta: Rineka Cipta.

Slameto.2015. Belajar Dan FaktorFaktor Yang Mempengaruhinya. Jakarta: PT Asdi Mahasatya.

Sudjana. 2015. Metoda Statistika. Bandung: Tarsito.

Sukardi. 2013. Metode Penelitian Pendidikan Tindakan Kelas. Jakarta: PT Bumi Aksara.

Tampubolon, Saur. 2014. Penelitian Tindakan Kelas. Jakarta: Penerbit Erlangga

Trianto.2013. Mendesain Model Pembelajaran InovatifProgresif. Jakarta: Kencana Prenada Media Group.

Wina Sanjaya. 2013. Strategi Pembelajaran Berorientasi Standar Proses Pendidikan. Jakarta: Kencana Prenada Media Group. 